\title{
EFFECT OF SULPHUR DIOXIDE ON GROWTH, CHLOROPHYLL AND SULPHUR CONTENTS OF POMEGRANATE
}

\author{
Swain $\mathrm{SC}^{1} *$ and Padhi $\mathrm{SK}^{2}$ \\ ${ }^{1}$ College of Agriculture, Orissa University of Agriculture and Technology, Bhawanipatna-766001, Kalahandi, \\ Odisha, India \\ ${ }^{2}$ IBCS, S,O"A University, Bhubaneswar-751030, Odisha, India \\ Department of Crop Science, Faculty of Agriculture, Eastern University of Sri Lanka, Chenkalady, Sri Lanka
}

Accepted: 8 January 2013

\begin{abstract}
The direct toxic effect of atmospheric pollutant such as sulphur dioxide on plants has been well documented. It is essentially a potent phytotoxic gas and its toxicity to plant is manifested in typical chronic or acute foliar symptom injury. The mode and extent of damage caused by this pollutant to pomegranate has not been precisely and systematically studied. Under such circumstances, the present investigation was undertaken under simulating condition to find out the possible extent of adaptability of pomegranate in $\mathrm{SO}_{2}$ emission of our state. The effect of varying levels of sulphur dioxide $(0.25,0.5$ and $1.0 \mathrm{ppm})$ fumigated for 1,2 and $3 \mathrm{~h}$ under simulated conditions on pomegranate revealed that the important traits like leaf number, leaf area, fresh weight, dry weight and chlorophyll content in leaves were adversely affected by $\mathrm{SO}_{2}$ level. $\mathrm{SO}_{2} 1.0 \mathrm{ppm}$ with $3 \mathrm{~h}$ exposure found to be more harmful. However, no significant variation was seen amongst the treatments in respect of tissue fresh and dry weight when compared with that of control (ambient $\mathrm{SO}_{2}$ ). On the other hand, sulphur content in tissues increase progressively with increasing levels of $\mathrm{SO}_{2}$ and time of fumigation and the variation observed within treatments was significant to each other. It is suggested that the lowest concentration of $\mathrm{SO}_{2}(0.25 \mathrm{ppm})$ used in this study is more than sufficient to bring about a significant changes in most of the parameters studied.
\end{abstract}

Key words: $\mathrm{SO}_{2}$ fumigation, pomegranate, growth, chlorophyll, sulphur content

\section{INTRODUCTION}

The continued expansion of industrial activity and urbanization worldwide are the main factor contributing to gaseous air pollution. Among the gaseous pollutant, $\mathrm{SO}_{2}$ is the primary pollutant because it is directly emitted from the pollution source as a product of combustion or processing of raw material that contain sulphur. The principal sources of $\mathrm{SO}_{2}$ are burning of coal and oil with high sulphur content and smelting of sulphide ore. The direct toxic effect of atmospheric pollutants, sulphur dioxide in particular, on plants has been well documented (Rajput et al.1977 and Winner et al.,1985 ) during the past two decades. It is essentially a potent phytotoxic gas and its toxicity to plant is manifested in typical chronic or acute foliar symptom injury. The relationship between foliar loss due to $\mathrm{SO}_{2}$ exposure and yield reduction in various crops has also been studied by Barreti and Benedict (1970) and Winner et al. (1985). It has been known to cause injury in these crops by destroying chlorophyll, disrupting photosynthesis and reducing biomass production and productivity. Moreover, the extent of injury is species dependent and is likely to be influenced by the macro and micro-climate of that particular agro-ecosystem. The natural adaptability of a crop species to a particular ecosystem is determined taking into consideration the extent of injury and sustainability of that crop. The mode and extent of damage caused by this pollutant to pomegranate has not been precisely and systematically studied. The present investigation is a modest attempt under simulating condition which aims at finding out the possible extent of adaptability of pomegranate in $\mathrm{SO}_{2}$ emission of our state.

\section{MATERIALS AND METHODS}

The investigation was carried out during 20062007 in the Regional Research and Technology Transfer Station (RRTTS), Orissa University 
of Agriculture and Technology, Semiliguda, Koraput, Orissa, India. The plants were raised in $45 \mathrm{x} 20 \mathrm{~cm}$ polythene bags filled with a mixture of soil (red lateritic having a $\mathrm{pH} 5.5$ ), sand and manure $(2: 1: 1)$. Sulphur dioxide for the study was prepared in the laboratory by heating copper turnings with conc. sulphuric acid. The gas is taken to the experimental plot where it is applied to the plants in the morning. The gas was brought in and applied to the chamber by keeping the volumetric flask upside down and opening the lid inside the chamber. Time to time stirring was done inside the chamber for uniform mixing of gas. The fumigation was given to the plants on the one and half year old seedlings. Sulphur dioxide gas was applied at three different concentrations i.e. at $0.25,0.5$ and $1.0 \mathrm{ppm}$ for different duration i.e. for 1,2 and $3 \mathrm{~h}$, by putting the plants in a specialized structure built in the dimension of $1 \times 1 \times 1 \mathrm{~m}$ length, breadth and width covered with high density polythene strip. The treatments were replicated thrice and fitted into a factorial randomized block design. All the operations were performed on the same day. Observations on growth, flowering and fruiting were recorded seven days after the treatment. In general, $\mathrm{SO}_{2}$ damage was assessed on the basis of its area affected. The damage exceeding more than $50 \%$ of its total area was considered as completely affected and less than $50 \%$ was considered as to be normal. The chlorophyll content was calculated by using the formula by Machlachan and Zalik (1963) and the procedure for sulfur estimation was adopted from Patterson (1978).

\section{RESULTS AND DISCUSSION}

Number of leaf and leaf area: Data pertaining to various traits revealed that damage to leaf injury, which includes both leaf number and its area, increased progressively in pomegranate studied with increasing levels of $\mathrm{SO}_{2}$ and time of fumigation (Table 1). Moreover, the damage was highly significant at the highest level of $\mathrm{SO}_{2}(1.0 \mathrm{ppm})$ when compared to that of control. In the present study, percent injury re- corded for leaf number and leaf area was in order of 12.9 to 52.5 and 16 to 42 , respectively. The injury manifested might be attributed to higher sulphur content in plant and as such the plant could not be capable of metabolizing and utilizing the $\mathrm{SO}_{2}$ absorbed outwardly (Stratigakos and Ormrod 1985). Such injury has been ascribed to the faster accumulation of $\mathrm{SO}_{2}$ than its oxidation and assimilation in the plant tissues, exceeding threshold accumulation in the intercellular spaces of the leaf and causing cell injury (Thomas 1961). Alternately, it has also been contemplated that $\mathrm{SO}_{2}$ in combination with aldehydes and sugars forms secondary products which decompose slowly to release $\mathrm{H}_{2} \mathrm{SO}_{3}$ or $\mathrm{H}_{2} \mathrm{SO}_{4}$ into the plant cell, that becoming more uninnocuous to the system (Haselhoff and Lindau, 1903).

Fresh and Dry matter content: Decrease in fresh weight and dry weight of the tissues was gradual with increasing concentrations of $\mathrm{SO}_{2}$ (Table 1). The values obtained in respect of the above parameters seem to be inconsistent when compared with that of control. The treatment effect was not significant although there was a marked difference in the data pertaining to this parameter. Further, reduction in the fresh and dry matter was more manifested in shoot than in root of plants. The present findings are in agreement with the results of Mandal et al. (1980) and Thompson et al. (1982)

Chlorophyll content: The chlorophyll content of leaves declined significantly with increaseing levels of $\mathrm{SO}_{2}$. Reduction in chlorophyll content determine to be 52 to $83 \%$, lowest value being recorded at $1.0 \mathrm{ppm} \mathrm{SO}_{2}$ treatment fumigated for $3 \mathrm{~h}$ (Table 1). Greater damage to the chloroplast machinery due to the $\mathrm{SO}_{2}$ treatment is the main cause of decrease in chlorophyll content in the leaves. The chlorophyll content decreased with increasing $\mathrm{SO}_{2}$ concentration and the effect is being more accentuated when the simulation period is increased. The decrease in chlorophyll content has been ascribed to the disruption of the chloroplast membrane due to phytotoxic nature of $\mathrm{SO}_{2}$, 
(Winner et al. 1985) resulting in leaching of pigments (Rath et al. 1994). Such interference of $\mathrm{SO}_{2}$ is believed to promote secondary processes which breakdown chlorophyll and kills the cells.

Sulphur content: The sulphur content in pomegranate plant tissues increased with increase in levels of $\mathrm{SO}_{2}$ fumigation (Table 1). Increase in sulphur content of tissues with increasing levels of $\mathrm{SO}_{2}$ is probably due to in- ability of plants to metabolize and assimilate the excess $\mathrm{SO}_{2}$ at cellular level thus results in its accumulation to manifold. This is quite natural and is also evident from the earlier report of Mishra, 1980 and Rath et al. (1994). Apparently, $\mathrm{SO}_{2}$ can cause some growth reduction in the absence of visible manifestation when a threshold concentration is exceeded. Under these conditions, it appears that $\mathrm{H}_{2} \mathrm{SO}_{3}$ or $\mathrm{SO}_{4}^{-2}$ can accumulate in the cells of the plants and inhibit photosynthesis without necessarily killing the cells. At sub-threshold

Table 1: Effect of varying level of $\mathrm{so}_{2}$ simulation on growth parameters, chlorophyll and sulphur contents in plant tissue of pomegranate

\begin{tabular}{|c|c|c|c|c|c|c|c|c|c|c|c|c|}
\hline \multirow{3}{*}{$\begin{array}{l}\text { Treatment } \\
\text { Parameter }\end{array}$} & \multicolumn{9}{|c|}{ ( oncentration of $\mathrm{SO}_{2}(\mathrm{ppm})$} & \multirow{3}{*}{$\begin{array}{c}\begin{array}{c}\text { Con- } \\
\text { trol }\end{array} \\
\text { T0H0 }\end{array}$} & \multirow{3}{*}{$\begin{array}{c}\text { F } \\
\text { Test }\end{array}$} & \multirow{3}{*}{$\begin{array}{l}\text { LSD } \\
\text { at } 5 \%\end{array}$} \\
\hline & \multicolumn{3}{|c|}{0.25} & \multicolumn{3}{|c|}{0.50} & \multicolumn{3}{|c|}{1.0} & & & \\
\hline & 1h & $2 \mathrm{~h}$ & $3 \mathbf{h}$ & 1h & $2 h$ & $3 \mathbf{h}$ & $1 \mathrm{~h}$ & $2 \mathbf{h}$ & $3 \mathbf{h}$ & & & \\
\hline \multicolumn{13}{|l|}{ No of leaves } \\
\hline Initial & 628 & 565 & 578 & 560 & 540 & 620 & 701 & 670 & 590 & 625 & & \\
\hline Damaged & 81 & 102 & 136 & 142 & 220 & 282 & 313 & 315 & 310 & $\mathbf{0 . 0}$ & & \\
\hline$\%$ Injury & 12.9 & 18.1 & 23.5 & 25.3 & 40.7 & 45.48 & 44.6 & 47.1 & 52.5 & $\mathbf{0 . 0}$ & $*$ & 4 \\
\hline \multicolumn{13}{|c|}{ Leaf area $(\mathrm{cm} 2)$} \\
\hline Initial & 5589 & 5028 & 5144 & 4984 & 4806 & 5518 & 6238 & 5963 & 5251 & 5562 & & \\
\hline Damaged & 894 & 1106 & 1337 & 1395 & 1441 & 1931 & 1996 & 2146 & 2204 & $\mathbf{0}$ & & \\
\hline$\%$ Injury & 16 & 22 & 26 & 28 & 30 & 35 & 32 & 36 & 42 & $\mathbf{0}$ & $*$ & 5.32 \\
\hline \multicolumn{13}{|c|}{ Fresh Weight (g) } \\
\hline Shoot & 376 & 322 & 306 & 257 & 253 & 285 & 350 & 274 & 230 & 325 & NS & \\
\hline Root & 53 & 56 & 57 & 58 & 56 & 55 & 53 & 55 & 54 & 60 & NS & \\
\hline S/R Ratio & 7.1 & 5.7 & 5.37 & 4.4 & 4.5 & 5.1 & 6.6 & 4.9 & 4.2 & 5.4 & NS & \\
\hline \multicolumn{13}{|c|}{ Dry Weight (g) } \\
\hline Shoot & 30 & 27 & 27 & 26 & 26 & 29 & 33 & 32 & 28 & 42.5 & NS & \\
\hline Root & 8 & 7 & 8 & 8 & 9 & 7.5 & 8.5 & 9 & 9 & 9 & NS & \\
\hline S/R Ratio & 3.75 & 3.8 & 3.3 & 3.2 & 2.8 & 3.8 & 3.8 & 3.5 & 3.1 & 4.7 & NS & \\
\hline \multicolumn{13}{|c|}{ Chlorophyll content (mg/g) } \\
\hline Fresh Leaf & 3.23 & 3.1 & 2.8 & 3 & 2.6 & 2.3 & 2.31 & 2.1 & 2 & 3.8 & $*$ & 0.34 \\
\hline$\%$ of Control & 83 & 80 & 75 & 79 & 68 & 61 & 60 & 56 & 52 & 100 & & \\
\hline \multicolumn{13}{|c|}{ Sulphur content } \\
\hline (ppm) & 0.08 & 0.09 & 0.10 & 0.11 & 0.12 & 0.13 & 0.13 & 0.14 & 0.15 & 0.06 & $*$ & 0.07 \\
\hline
\end{tabular}

*- F. Test Significant, NS - Not Significant 
concentrations, the sulphite is oxidized to the non-toxic sulphate as rapidly as it is absorbed, so that inhibition of photosynthesis does not occur. Similarly, at concentrations below those causing any visible symptoms, cause a reduction of photosynthesis, early senescence, an unthrifty appearance, reduce growth and yield, and increase susceptibility to disease and insects.

\section{CONCLUSION}

Sulphur dioxide treatments in pomegranate were found to be harmful even at lower dose and duration of exposure which increased gradually with increasing concentrations and durations. However, lower concentration i.e. at $0.25 \mathrm{ppm}$ of $\mathrm{SO}_{2}$, the injuries to various morpho-physiological parameters were subtle. It is suggested that the lowest concentration of $\mathrm{SO}_{2}(0.25 \mathrm{ppm})$ used in this study is more than sufficient to bring about a significant changes in most of the parameters studied. However basing on the present results it is hoped that this preliminary study would throw a light to the researchers and environmentalist from the view of increasing day to day global pollution and its effect on crop canopy as a whole.

\section{REFERENCES}

Barretti, TW and Benedict, H W 1970 Sulphur dioxide in recognition of air pollution injury to vegetation: A pictorial atlas ( Eds. Jacobsons,T. S. and Hills, A.C., ). Air pollution Control Association, Pittsburg, pp:1-17.

Haselhoff E and Lindau G 1903 Die deschadigung der vegetation durch rauch, Borntreger, Leipzig.

Machlachan S and Zalik S 1963 Plastid structure, chlorophyll concentration and free amino acid composition of a chlorophyll mutant of barely. Canadian J. Bot. 41: 1053-62.

Mandal RH, Weinstein LH, Dean M and Monica W 1980 The response of sweet corn to $\mathrm{HF}$ and $\mathrm{SO}_{2}$ under field conditions. Environ. Expt. Bot. 20: 359-365.
Mishra LC 1980 Effects of sulphur dioxide fumigation on ground nut (Arches hypogaea L.) Environ. Expt. Bot. 20:397-400.

Patterson GDR 1978 Colorimetric determination of non material. Inter Science, New York. $308 \mathrm{p}$.

Rajput CBS, Ormrod DP and Evans WD 1977 The resistance of strawberry to Ozone and sulphur dioxide. Plant Disease Reporters, 61: 222-225.

Rath S, Padhi SK, Kar MR and Ghosh PK 1994 Response of zinnia to sulphur dioxide exposure. Ind. J. Ornamental Hort., 2 (1\&2): $42-45$.

Stratigakos A and Ormorod DP 1985 Response of tomato to sulphur nutrition and $\mathrm{SO}_{2}$. Water, air, soil, pollut. 247(1) : 19-26.

Thomas MD 1961 Effect of air pollution on plants in "Air Pollution" W.H.O (Geneva) Monoger, No.46, pp:233-278.

Thompson CR, Gerrit K and Philip JD 1982 Low level effects of $\mathrm{H}_{2} \mathrm{~S}$ and $\mathrm{SO}_{2}$ on grapevines, pear and walnut trees. Hort. Sci., 17 (2): 233-235.

Winner WE, Mooney HA and Goldstun RA 1985 Sulphur dioxide and vegetation: Physiology, ecology, and policy issues. Standard Univ. Press, Stanford, C.A. 